\title{
Effects of wave exposure on the community structure of a plant-dominated, fringing-reef platform: intermediate disturbance and disturbance-mediated competition
}

\author{
John A. Kilar ${ }^{1, *}$, J. McLachlan ${ }^{2}$ \\ ${ }^{1}$ The Smithsonian Tropical Research Institution, PO Box 2072, Balboa, Panama \\ and Department of Biology, Dalhousie University, Halifax, Nova Scotia, Canada, B3H 4J1 \\ ${ }^{2}$ National Research Council, 1411 Oxford Street, Halifax, Nova Scotia, Canada, B3H 3Z1
}

\begin{abstract}
Effects of wave-exposure on a fore-reef community were investigated by quantitative biomass sampling and field manipulations at Galeta Point, Caribbean Panama. Three predictions of Connell's (1978) intermediate-disturbance hypothesis are examined: (1) community diversity should be low in highly disturbed habitats, as few species can tolerate extreme biotic and abiotic conditions; (2) community diversity should be low in benign habitats, as most species are excluded by the competitive dominants; and (3) maximal community diversity should occur at intermediate conditions, as neither competition nor disturbance exert a dominating influence. In general, data support the intermediatedisturbance model. The predictions apply best to guilds of species that occupy primary substratum and are directly affected by wave-induced disturbance and space-light competition. Species adapted to environmental extremes or associated with the competitive dominants may be equally important in determining community richness. Tolerance to disturbances defines which species become dominant. Habitat complexity, competition, and mutualism secondarily influence the composition of this community. Selection for competitive ability among seaweeds becomes increasingly important in benign environments. Throughout most of the fore-reef zone, Laurencia papillosa is the competitive dominant, as defined by its ability to sequester and dominate space. As wave exposure subsides, Acanthophora spicifera competitively reduces the abundance of $L$. papillosa in some microhabitats. Spatial-temporal conditions determine the superior competitor. A balance among competitive abilities, mutualistic interactions, and tolerances to distrubances promotes the coexistence of these species.
\end{abstract}

\section{INTRODUCTION}

A central issue in ecology is the impact of competition and disturbance on organisms, populations and communities. Competition results from reductions in resource availability either by exploitation - depleting a resource - or interference - restricting access to a resource (Kreb 1978). Disturbance consists of physical and biological mechanisms which limit the abundance or distribution of organisms by causing their destruction (Grime 1979) or restricting their growth and reproduction. The paradigm is that periodic disturbances prevent competitive exclusion and maintain species

- Present address: Mote Marine Laboratory, 1600 City Island Park, Sarasota, Florida 34236, USA diversity (Paine 1966, Connell 1970, Dayton 1971, Menge 1976), with the number of dominant species related to habitat complexity (MacArthur \& Levins 1964). Theoretically, competition can achieve similar results through coevolutionary mechanisms, leading to niche-diversification (i.e. as character displacement or convergence) or changes in competitive ability (Arthur 1982). Although several equilibrium and non-equilibrium models attempt to explain community diversity (Hutchinson 1961, Janzen 1970, Jackson \& Buss 1975, Tilman 1980), only Connell's (1978) intermediate disturbance hypothesis emphasizes the importance of distrubance and competition in shaping natural communities. Species diversity is predicted to be high when disturbances are at intermediate intensities or frequencies, and low at their extremes, resulting from 
intense interspecific competition or low tolerances to biotic or abiotic conditions. Numerous studies have shown recurrent natural disturbances in the forms of wave exposure or shock, tidal emersions, grazing, sedimentation, and light to affect the development and structure of marine communities (reviewed by Connell $\&$ Keough 1985). There is, however, little evidence for a hump-shaped diversity pattern along gradients of disturbance in marine ecosystems (Paine \& Vadas 1969, Loya 1976, Geister 1977, Osman 1977, Lubchenco 1978, Grigg 1983), despite the model's trend towards becoming an accepted generalization

In this paper, we examine the effects of a waveexposure gradient on the fore-reef community of a Panamanian fringing reef. We ask the question, does Connell's (1978) intermediate disturbance hypothesis explain the pattern of benthic assemblages along the fore reef? To examine the predictions of the model, diversity indices are calculated, wave-exposure damage is assessed, and competitive interactions are described between the 2 dominant macrophytes Acanthophora spicifera (Vahl) Børgesen (hereafter Acanthrophora) and Laurencia papillosa (Forsskål) Greville (hereafter 'Laurencia).

\section{METHODS}

Study site. Research was done on the reef flat adjacent to the Galeta Marine Laboratory, Smithsonian Tropical Research Institute (STRI), located at Galeta Point, Caribbean Panama $\left(9^{\circ} 24.3^{\prime} \mathrm{N}, 79^{\circ} 51.8^{\prime} \mathrm{W}\right)$. Fleshy macroalgae dominated the fore- and back-reef areas, previously described as the Laurencia and Acanthophora zones, respectively (Fig. 1; Birkeland et al. 1976). Between these zones, the seagrass Thalassia testudinum Bank ex König \& Sims predominates (Thalassia zone). Acanthophora also occurs in a narrow zone (Acanthophora subzone) within the much broader, fore-reef Laurencia zone.

During the dry season, mid-November to March, northern and northeasterly trade winds blow at a mean velocity of 24 to $27 \mathrm{~km} \mathrm{~h}^{-1}$ (Hendler 1976), about 3 times the mean velocity in the wet season, April to midNovember. Waves generated by these strong winds increase turbidity and remove weakly attached algae. As the strength of waves generated in the open sea is modified by the shallow-water environment, a gradient of wave exposure is established along the fore reef (Kilar 1984). The elevation of the reef is greatest in the

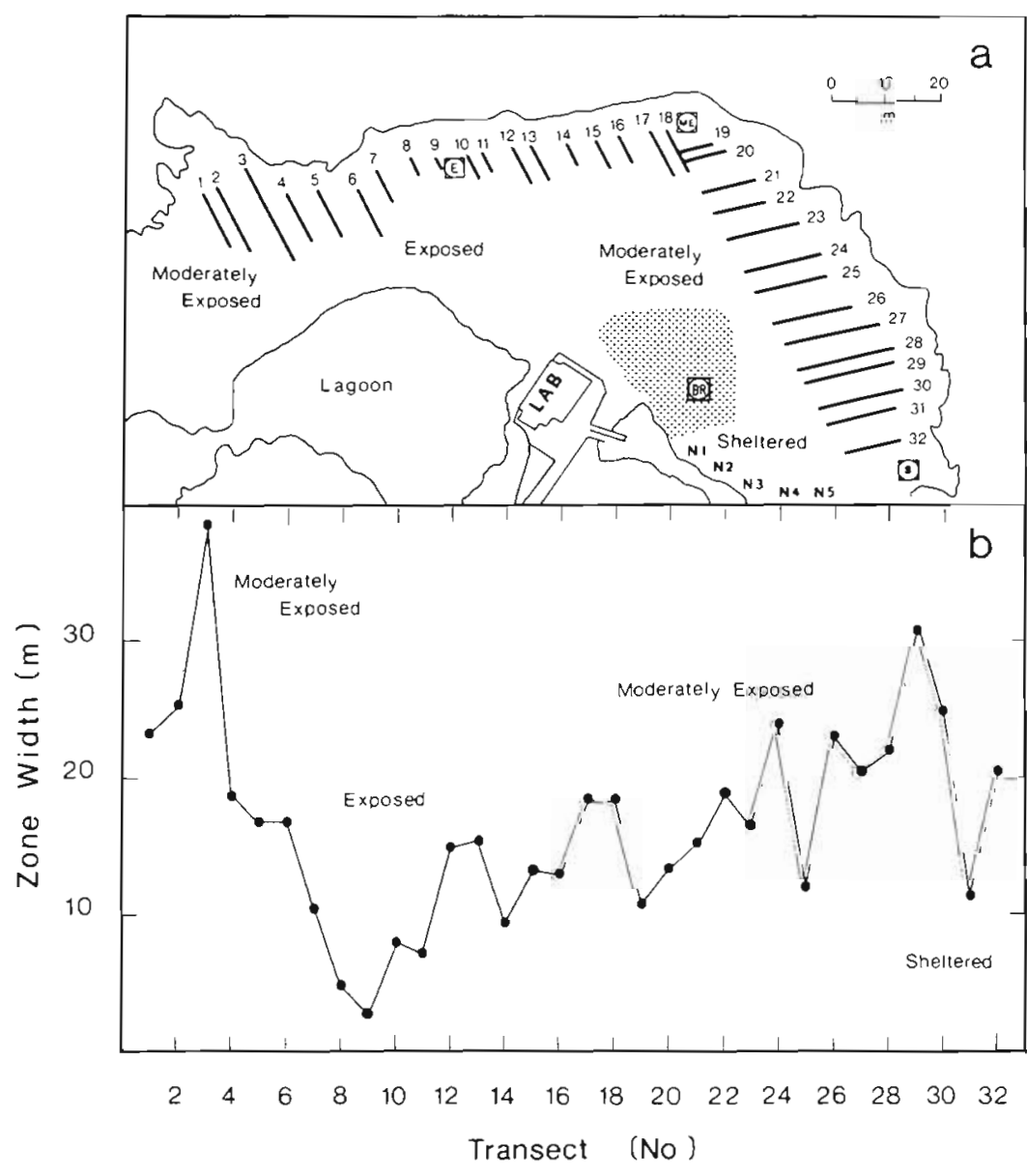

Fig. 1. (a) Station, net (N1 to 5), and transect locations (1 to 32) on the reef platform at Galeta Point, Panama. E: Exposed station; ME: Moderately-Exposed station; S: Sheltered station; BR: Back-Reef station; stippled area: Acanthophora zone. (b) Laurencia zone width and transect lengths 
fore reef, and with prevailing winds, water flows almost unidirectionally over the platform. During the wet season, when calm seas coincide with a low pressure system or with low spring tides, episodic tidal emersions of the platform occur (Hendler 1977). Exposure periods of several days to weeks kill slow-moving herbivores, reduce algal cover (Glynn 1968, Hendler 1976 , 1977), and cause local extinctions (Kilar et al. in press). More detailed lists of species, descriptions of communities, and work done at Galeta are available (see Cubit \& Williams 1983, Connor 1985).

Physical disturbance. Water velocity and wave force data were collected throughout the platform and at 4 stations: Exposed, Moderately-Exposed, Sheltered and Back-Reef stations (Fig. 1). During moderate sea-conditions, velocities of incoming wave surge, backwash, and water motion to the left and right of the incoming waves were simultaneously measured, using a MarshMcBirney Multidirectional Electromagnetic Water Current Meter (Model 511). Instantaneous measurements of water flow were recorded for a 15 -min period and compiled at 1 -min intervals. Data are displayed in Fig. 2 as vector diagrams. Wave force was measured daily over a fortnight with a dynamometer (Denny 1983). As there was close agreement between water velocity (incoming surge) and wave force measurements, only water velocity data are presented (for wave-force data, see Kilar 1984).

From November 1979 to March 1980, drift biomass was continuously collected to determine whether wave-induced losses of algae and seagrass were different with wave-exposure. Net description and sampling procedure are those of Kilar \& Norris (1988). Five nets collected drift just before it left the platform (approximate locations in Fig. 1). Net positions were selected to maximize the collection of drift biomass. Only biomass originating from the platform is reported.

To determine the location along the wave-exposure gradient sampled by each net, marked tags ( $n \geq 1000$ ) were released upstream from predetermined locations in the Laurencia and Thalassia zones. Tags consisted of neutrally buoyant, fluorescent surveyor's tape (ca $3 \times 3 \mathrm{~cm}$ ), each numerically labeled. Initially, different sized tags were tested against fragments of Acanthophora and Laurencia. After $48 \mathrm{~h}$, tags in each net were noted for their place of release. The procedure was repeated in different sea conditions.

Competitive interactions. At the ModeratelyExposed station (Acanthophora subzone) estimates of height, the distance from the base to the distal tip of an alga, were used to determine if Acanthophora and Laurencia influenced each other's growth. Monitoring began after a period of tidal emersion when the algae were reduced to their residual holdfast. After 1 and $5 \mathrm{wk}, 3$ categories of fronds ( $n \geq 87$ ) were compared:
(1) Acanthophora adjacent to Laurencia; (2) Laurencia shaded by Acanthophora; and (3) Laurencia without nearby Acanthophora. Fronds were collected randomly along a $10 \mathrm{~m}$ transect.

Reciprocal removal-experiments of Acanthophora and Laurencia were done at the Sheltered and BackReef stations. At the Sheltered station, 6 plots $(0.3 \times 0.6 \mathrm{~m})$ were randomly selected in areas where both species were similarly represented. Two treatments were established by dividing each plot in half. At random, one-half of each plot was cleared of and maintained free from Laurencia, while the other half served as a control. After $3 \mathrm{mo}$, the biomass of Acanthophora was harvested and compared.

Conversely, the removal of Acanthophora was done from 6 plots at the Back-Reef station. The experiment was conducted at this location to minimize the overall damage to the Sheltered station. Differences in algal densities were not significant between these locations, as indicated by transmitted-light data (Kilar 1984). After $6 \mathrm{mo}$, the standing crop of Laurencia was harvested.

Community structure. Shannon \& Weaver's (1949) index of diversity, Pielou's (1975) evenness index. species richness, standing crop $\left(g[d r y w t] \mathrm{m}^{-2}\right)$, and occurrence (no. of samples with a species/total no. of samples) were calculated for each of 32 transects from the data of Kilar et al. (in press), restricting data to the Laurencia zone and the dry-season months to maximize the effects of the wave-exposure gradient. Hereafter, species diversity refers to the ShannonWeaver index and not species richness.

Standing crop estimates of benthic assemblages at the Exposed, Moderately-Exposed, and Sheltered stations were collected in December 1981 to determine the abundance, richness, and diversity of benthic assemblages in the Acanthophora subzone. A transect, perpendicular to incoming waves and encompassing the entire Laurencia zone, was haphazardly selected and sampled in a uniform manner; 1 sample was collected at $0.5 \mathrm{~m}$ intervals, with 3 additional samples collected at $0.5 \mathrm{~m}$ intervals to the left of the initial sample. Where Acanthophora was most abundant, a $10 \mathrm{~m}$ transect parallel to the incoming wave surge was sampled in a stratified random fashion, with 1 sample collected within every $0.5 \mathrm{~m}$. Samples were returned to the laboratory and treated as previously described. This procedure provided a nonstatistical method to remove 'area effects' when testing the intermediate-disturbance model.

The presence and absence of species from all possible pairs of transects were compared by a 'Simple Matching Coefficient' (Sokal \& Michener 1958) subjected to a hierarchical cluster analysis and a group averaging clustering strategy. Our selection of this coefficient was based on the assumption that equal weight should be placed on species presence and absence (Romesburg 


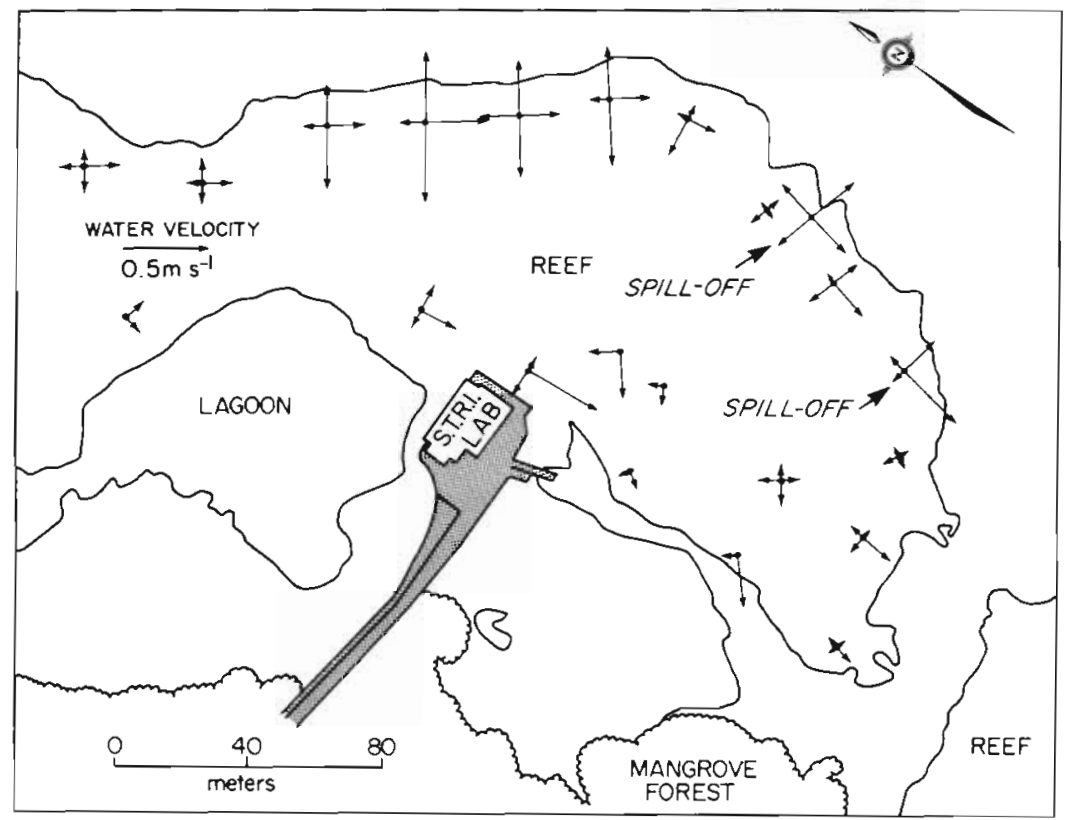

Fig. 2. Current velocity measured relative to incoming wave surge (5 December 1981). Vectors indicate relative speed and direction of water
1984). Pair-wise test of Shannon-Weaver diversity followed those of Hutcheson (1970). Further hypotheses were examined by $t$-test, ANOVA, ANCOVA, or regression statistics, using the techniques outlined by Sokal \& Rohlf (1981) and Pimentel \& Smith (1986).

\section{RESULTS}

\section{Physical disturbances}

Along the fore-reef, water velocities were highest near Transects 7 to 14 , moderate near Transects 1 to 3 and 20 to 26, and lowest near 28 to 32 (Fig. 2). Spill-off areas (sensu Kilar 1984) occurred along the edge of the reef platform, distorting the gradient in small, localized areas. Water velocity decreased into the back reef. Measurements of incoming wave surge were higher than those of retreating water or backwash $\left(F_{3,240}=75\right.$, $p<0.001$, Student-Newman-Keuls test, SNK, $p<$ $0.05)$, and there was a net flow of water to the right of the incoming surge (i.e. long-shore current). Wave surge velocities were significantly different among stations $\left(F_{3,63}=119, p<0.001\right)$, decreasing significantly in intensity from the Exposed to the Sheltered station (SNK, $p<0.05$ ).

Net 1 collected marked tags originating between Transects 8 and 15, Net 2 between 10 and 15, Net 3 between 13 and 17 , Net 4 between 15 and 21, and Net 5 between 20 and 28. Nets 1 to 3 sampled drift algae and seagrasses from wave-exposed sites, and Nets 4 to 5 from moderately-exposed to sheltered sites; a pattern which did not vary with sea condition.
Nets collected significantly different quantities of biomass $\left(F_{4.104}=7.3, p<0.001\right)$, with the most biomass originating from areas in and behind exposed, fore-reef habitats (Fig. 3). Drift biomass consisted mainly of Thalassia testudinum, Laurencia and Acanthophora.

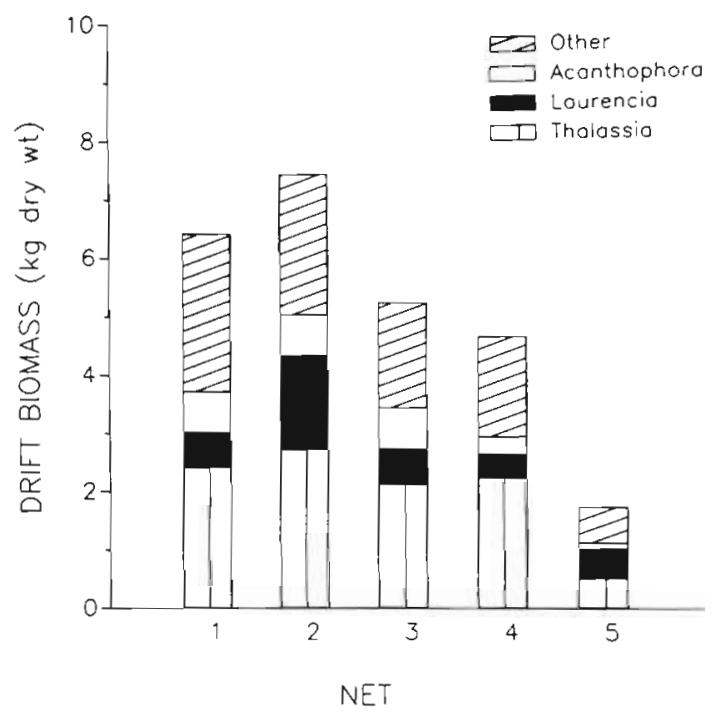

Fig. 3. Algal and seagrass biomass collected in 5 nets located on the downstream edge of the reef platform (November 1979 to March 1980). Nets 1 to 3 collected significantly more biomass than Net 5 , and Net 2 more than Net 4 (SNK, $p<0.05$ ).

\section{Competitive interactions}

After 1 wh of recovery from a tidal emersion, Acanthophora was more than twice the height of Laurencia. 
Table 1. Height (mm) of Acanthophora and Laurencia 1 and 5 wk after tidal emersion. Acanthophora always occurred in association with Laurencia. Laurencia was either shaded by Acanthophora or independent of it. Data are means \pm 1 standard error Values in parentheses = sample size. "No plants

\begin{tabular}{|c|c|c|}
\hline \multirow[t]{2}{*}{ Species association } & \multicolumn{2}{|c|}{ Period after emersion } \\
\hline & $1 w k^{a}$ & $5 w^{b}$ \\
\hline Acanthophora & $\begin{array}{c}77.3 \pm 0.7 \\
(88)\end{array}$ & $\begin{array}{c}32.6 \pm 1.4 \\
(200)\end{array}$ \\
\hline Shaded Laurencia & $\begin{array}{c}27.4 \pm 0.7 \\
(87)\end{array}$ & $\cdot$ \\
\hline Laurencia & $\begin{array}{c}29.5 \pm 0.6 \\
(99)\end{array}$ & $\begin{array}{c}39.2 \pm 1.7 \\
(200)\end{array}$ \\
\hline $\begin{array}{l}F_{2,272}=478, p<0.001 \\
p<0.05 \\
F_{1.399}=9.9, p<0.005\end{array}$ & all pairwis & parison $\mathrm{S}$ \\
\hline
\end{tabular}

Laurencia shaded by Acanthophora was shorter than plants not shaded (SNK, $p<0.05$ ). After $5 \mathrm{wk}$, the height of Acanthophora was reduced from 77 to $33 \mathrm{~mm}$ and was shorter than Laurencia (Table 1).

Acanthophora failed to increase in standing crop in plots cleared of Laurencia. After $3 \mathrm{mo}$, Acanthophora had been totally removed, while control plots had copious quantities of Acanthophora and Laurencia One year later, neither Acanthophora nor Laurencia recruited into the denuded plots, although Laurencia did encroach from the sides. After the loss of Acanthophora, mixtures of green (e.g. Bryopsis, Struvea) and red (e.g. Wrangelia, Centroceras, Ceramium) algae occupied these sites for different intervals, usually 1 to $4 \mathrm{mo}$.

After 6 mo, plots cleared and maintained free from Acanthophora had significantly greater standing crops of Laurencia than control plots (Table 2), suggesting that the growth of Laurencia was inhibited by Acanthophora.

\section{Community structure}

The standing crop of Laurencia increased with decreasing wave exposure in the Laurencia zone, ranging from a minimum of $184 \mathrm{~g} \mathrm{~m}^{-2}$ at the Exposed station to a maximum of $250 \mathrm{~g} \mathrm{~m}^{-2}$ at the Sheltered station. Estimates of Acanthophora standing crop were highest at the Moderately-Exposed station (Fig. 4; Table 3).

When sampling was confined to the Acanthophora subzone, the standing crops of Acanthophora and Laurencia were inversely related $\left(Y=274-0.27 X, r^{2}\right.$ $=0.29, p<0.001, n=60$ ). Acanthophora increased and Laurencia decreased along the wave-exposure gradient (Fig. 4). Where Acanthophora was most abundant at the Sheltered Station, the standing crop of Laurencia
Table 2. Standing crop (g [dry $w t] \mathrm{m}^{-2}$ ) of Laurencia in control plots and plots removed of Acanthophora. $t$ : 2-tailed paired sample t-test. Data are means \pm 1 standard deviation

\begin{tabular}{|lllcc|}
\hline & \multicolumn{2}{c}{ Treatment } & & \\
& $\begin{array}{c}\text { Non-removal } \\
\text { (control) }\end{array}$ & Removal & $t$ & $p$ \\
\hline $\begin{array}{l}\text { Laurencia } \\
\text { standing crop }\end{array}$ & $82.7 \pm 19.1$ & $229.5 \pm 52.9$ & 5.2 & $<0.001$ \\
\hline
\end{tabular}

was low but increased significantly in a landward and seaward direction (SNK, $p<0.05$; Table 4). Similar patterns were not observed at the Moderately-Exposed and Exposed stations, as Acanthophora did not occur in dense patches.

Four patterns of species abundance were observed as

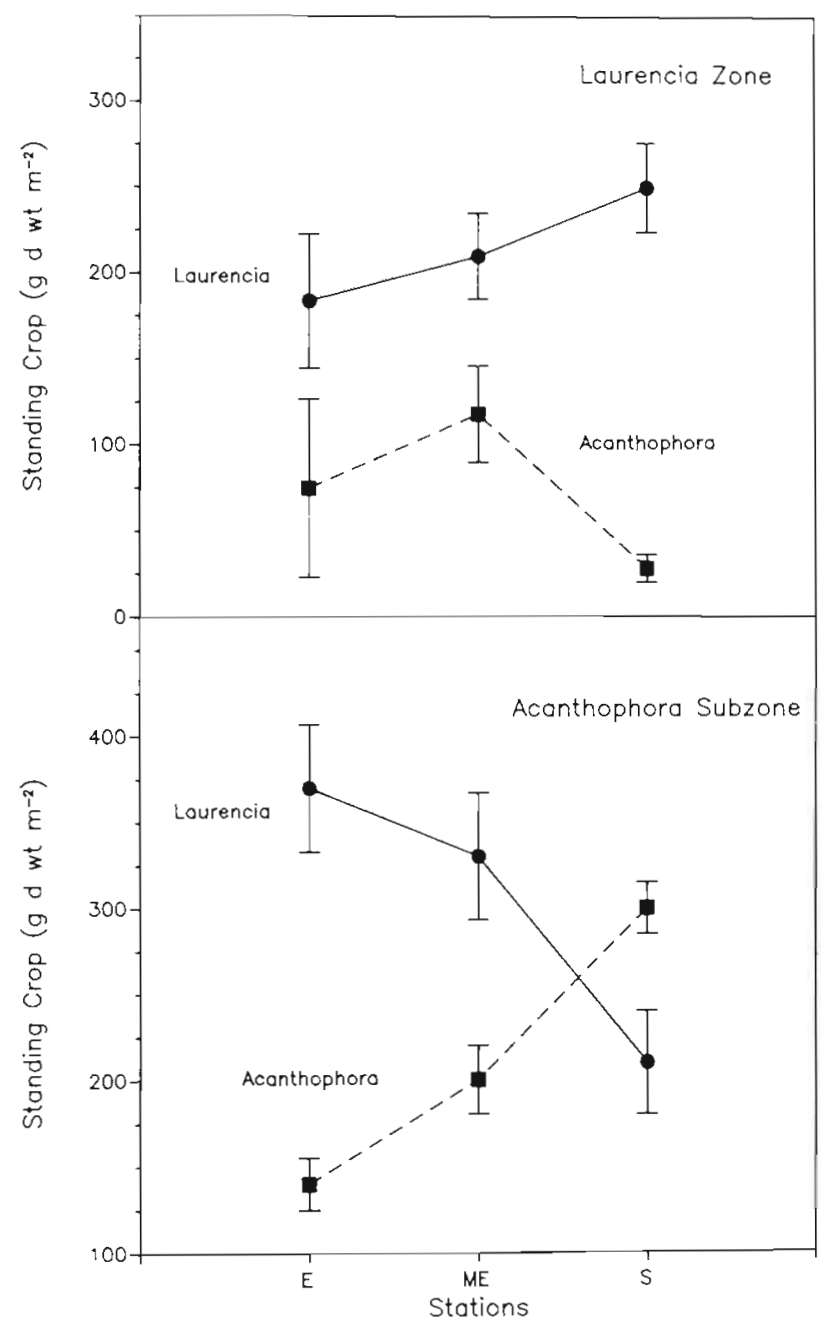

Fig. 4. Acanthophora and Laurencia standing crop at the Exposed (E), Moderately-Exposed (ME), and Sheltered stations (S) (December 1981). Vertical bars indicate \pm 1 standard error 
Table 3. Species abundance in the Laurencia zone at the Exposed, Moderately-Exposed, and Sheltered stations. Data represent standing crop (g [dry wt] $\mathrm{m}^{-2}$ ) or percent occurrence. With decreasing wave exposure, species abundance increased (i), decreased

(d), was highest at the Moderately-Exposed station (h) or was lowest at the Moderately-Exposed station (l). - Not collected

\begin{tabular}{|c|c|c|c|c|}
\hline \multirow[t]{2}{*}{ Species } & \multicolumn{3}{|c|}{ Stations } & \multirow[t]{2}{*}{ Pattern } \\
\hline & Exposed & Moderately-Exposed & Sheltered & \\
\hline \multicolumn{5}{|l|}{ 1. Competitive dominants } \\
\hline \multicolumn{5}{|l|}{ Flora } \\
\hline Acanthophora spicifera & $74.9 \pm 52.5$ & $117.9 \pm 28.4$ & $28.4 \pm 7.7$ & $\mathrm{~h}$ \\
\hline Amphiroa fragilissima & $49.1 \pm 19.8$ & $41.3 \pm 14.6$ & $38.7 \pm 20.7$ & $d$ \\
\hline Gelidiella acerosa & $19.8 \pm 2.6$ & $58.5 \pm 18.9$ & $112.7 \pm 11.2$ & $\mathrm{i}$ \\
\hline Halimeda opuntia & $1170.4 \pm 230.0$ & $802.9 \pm 153.2$ & $302.1 \pm 86.9$ & $\mathrm{~d}$ \\
\hline Laurencia papillosa & $184.2 \pm 38.7$ & $210.0 \pm 25.0$ & $250.4 \pm 25.8$ & $\mathrm{i}$ \\
\hline Fauna & - & - & - & \\
\hline Zoanthus sociatus & 3.8 & 10.5 & 20.3 & i \\
\hline Sponges & 23.1 & 33.7 & 37.0 & i \\
\hline \multicolumn{5}{|l|}{ 2. Sessile species } \\
\hline \multicolumn{5}{|l|}{ Flora } \\
\hline Acetabularia crenulata & - & 3.1 & 0.5 & $\mathrm{~h}$ \\
\hline Anadyomene stellata & - & - & 5.7 & i \\
\hline Ceramium sp. & 7.7 & 4.2 & 1.0 & $\mathrm{~d}$ \\
\hline Codium isthmocladum & 3.8 & - & - & $d$ \\
\hline Dictyosphaeria sp. & 3.8 & 3.2 & 5.2 & 1 \\
\hline Dictyota cervicornis & - & 7.3 & - & $\mathrm{h}$ \\
\hline Endolithic green algae & 50.0 & - & - & $\mathrm{d}$ \\
\hline Gelidium pusillum & - & 1.1 & 0.5 & $\mathrm{~h}$ \\
\hline Hypnea musciformis (epiphyte) & 7.7 & - & - & $d$ \\
\hline Hypnea spinella & 3.8 & 6.3 & 0.5 & $\mathrm{~h}$ \\
\hline Laurencia sp. & - & 5.2 & - & $\mathrm{h}$ \\
\hline Lithophyllum sp. & 73.1 & 96.8 & 84.4 & $\mathrm{~h}$ \\
\hline Struvea anastomosans & - & 1.1 & 3.1 & i \\
\hline \multicolumn{5}{|l|}{ Fauna } \\
\hline Bivalves & 7.7 & 20.0 & 10.4 & h \\
\hline Homotrema rubrums & 30.8 & 68.4 & 40.6 & $\mathrm{~h}$ \\
\hline Sea anemone & - & 2.1 & 1.0 & $\mathrm{~h}$ \\
\hline Sipunculids & 19.2 & 16.8 & 16.1 & $\mathrm{~d}$ \\
\hline Spiorbis sp. & - & 3.2 & 3.6 & $\mathrm{i}$ \\
\hline Vermeids & 3.2 & 5.0 & 0.5 & $\mathrm{~h}$ \\
\hline \multicolumn{5}{|l|}{ 3. Motile species } \\
\hline \multicolumn{5}{|l|}{ Fauna } \\
\hline Chitons & - & 2.1 & - & h \\
\hline Crabs & 11.5 & 14.7 & 13.5 & h \\
\hline Diadema antillarum & 3.8 & - & - & $d$ \\
\hline Echinonous sp. & 3.8 & - & 1.0 & 1 \\
\hline Eurythoa complanta & - & - & 1.0 & i \\
\hline Gastropods & 3.8 & - & - & $d$ \\
\hline Isopods & 7.7 & 4.2 & 4.2 & $d$ \\
\hline Nemerteans & - & 3.2 & 1.0 & $\mathrm{~h}$ \\
\hline Ophiocoma sp. & 11.5 & 6.3 & 1.5 & $d$ \\
\hline Polychaetes & 69.2 & 86.3 & 74.0 & $h$ \\
\hline Scale worms & - & 1.0 & - & $\mathrm{h}$ \\
\hline Shrimp & 7.7 & 2.1 & 3.6 & 1 \\
\hline Stematopods & - & 6.3 & 2.6 & $h$ \\
\hline
\end{tabular}

wave exposure subsides (Table 3): species abundance increased (e.g. Laurencia), decreased (e.g. Halimeda opuntia), was highest at intermediate intensities (e.g. Acanthophora) or lowest at intermediate intensities (e.g. Dictyosphaeria sp.). Of the 39 species, $43.6 \%$ exhibited maximum abundance at intermediate conditions.

Associations of transects classified by a similarity index and transect location reflected the pattern of wave exposure defined by prevailing reef-flat currents (Fig. 5). Transects with large numbers of species clustered independent of one another, due to the greater frequency of species mismatches. These stations were represented by Transects 1 to 3,15 to 18 and 20 to 26 and occurred at intermediate wave-exposure conditions. Transects 22, 23, and 26 formed a separate grouping. Transects 4 to 14 defined exposed habitats 
Table 4. Standing crop ( $\mathrm{g}$ [dry $\mathrm{wt}] \mathrm{m}^{-2}$ ) of Laurencia at the Sheltered station. Distance seaward and landward from the Acanthophora subzone. Values in parentheses = sample size

\begin{tabular}{|c|c|c|c|}
\hline & Landward & $\begin{array}{c}\text { Acanthophora } \\
\text { subzone }\end{array}$ & Seaward \\
\hline Distance (m) & 0.5 to 3.5 & 0.0 & 0.5 to 3.5 \\
\hline St. $\operatorname{crop}(\overline{\mathrm{x}} \pm S D)^{\mathrm{d}}$ & $\begin{array}{c}369 \pm 218 \\
(30)\end{array}$ & $\begin{array}{c}144 \pm 71 \\
(20)\end{array}$ & $\begin{array}{c}419 \pm 79 \\
(27)\end{array}$ \\
\hline \multicolumn{4}{|c|}{$\begin{array}{l}F_{2.76}=8.5, p<0.001 \text { (after } \ln x \text { transformation). Group } \\
\text { means were significantly greater landward and seaward } \\
\text { of the Acanthophora subzone (SNK, } p<0.05 \text { ) }\end{array}$} \\
\hline
\end{tabular}

\section{SIMILARITY}

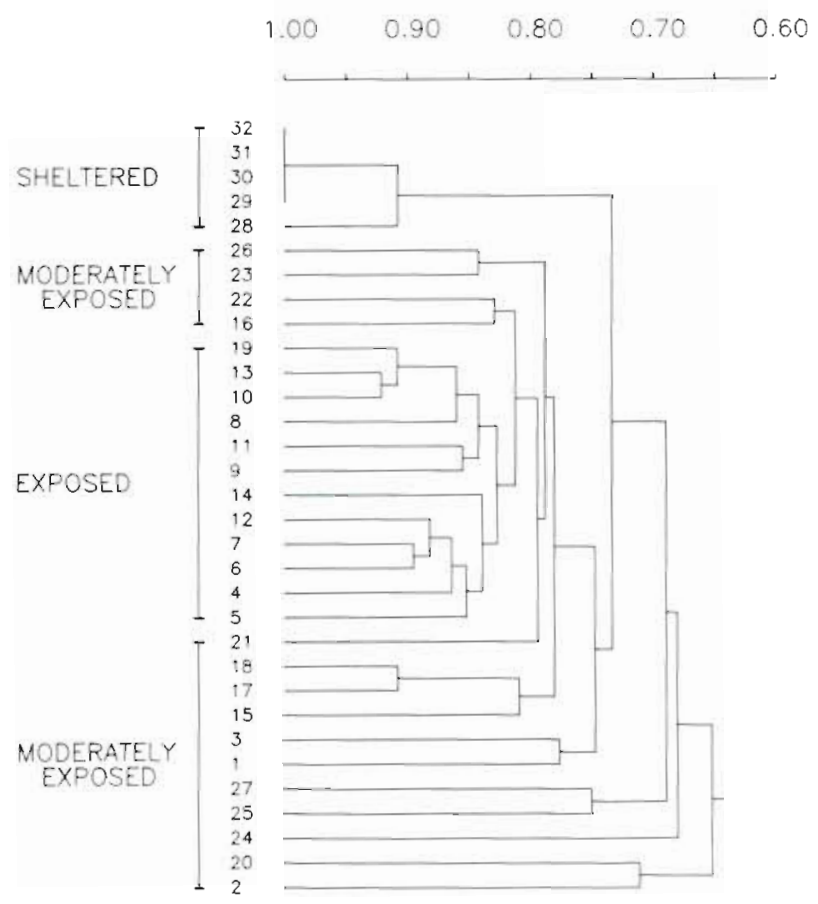

Fig. 5. Similarity dendrogram of benthic assemblages in the Laurencia zone transects

and Transects 28 to 32 sheltered habitats. Transect 19 was incongruous, sorting with exposed transects but surrounded by moderately-exposed transects (possibly related to log-damage).

Measurements of diversity, evenness, and richness for each of the 32 fore-reef transects are displayed in Figs. 6 and 7. Evenness and diversity measurements exhibited considerable within-habitat variability (i.e. comparisons between adjacent transects), while those of species richness were less variable. A pronounced pattern in floral richness occurred along the waveexposure gradient: Transects 5 to 15 (i.e. most exposed) and 31 to 32 (i.e. most sheltered) were species-poor and Transects 1 to 3 and 20 to 27 were species-rich. Other-

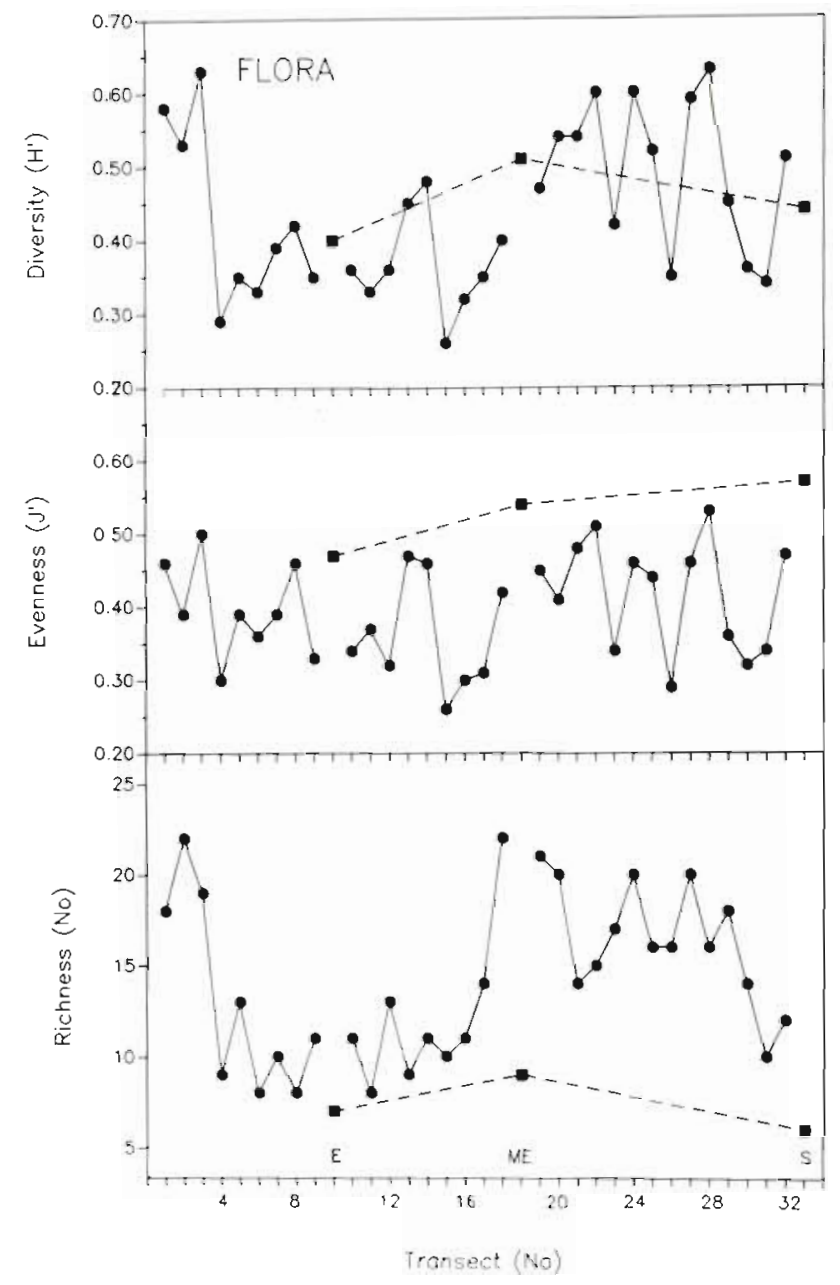

Fig. 6. Diversity, evenness, and richness of flora at each of the 32 Laurencia zone transects and at the Exposed (E), Moderately-Exposed (ME), and Sheltered (S) station transects (Acanthophora subzone)

wise, among the other indices, the pattern was to increase from exposed to moderately-exposed habitats and to change little between moderately-exposed and sheltered habitats.

Sampling area obscured the interpretation of diversity and richness data. Weak linear relations were observed when transect length was regressed against flora $\left(r^{2}=0.37, p<0.001\right)$ and fauna $\left(r^{2}=0.18\right.$, $p<0.01$ ) richness. We were not surprised by these results, as the width of the zone increased from exposed into sheltered habitats (Fig. 1). Using the width of the zone as a covariate and grouping transects to reflect wave exposure ( 7 to 14 exposed; 1 to 3 and 20 to 26 moderate; 38 to 32 sheltered; Fig. 2), flora and fauna richness were significantly different among habitats (flora, ANCOVA $F_{2,19}=25.1, p<0.001$; fauna, ANCOVA $F_{2,19}=4.2, p<0.029 ;$ after square-root transformation), with the moderately-exposed habitats 


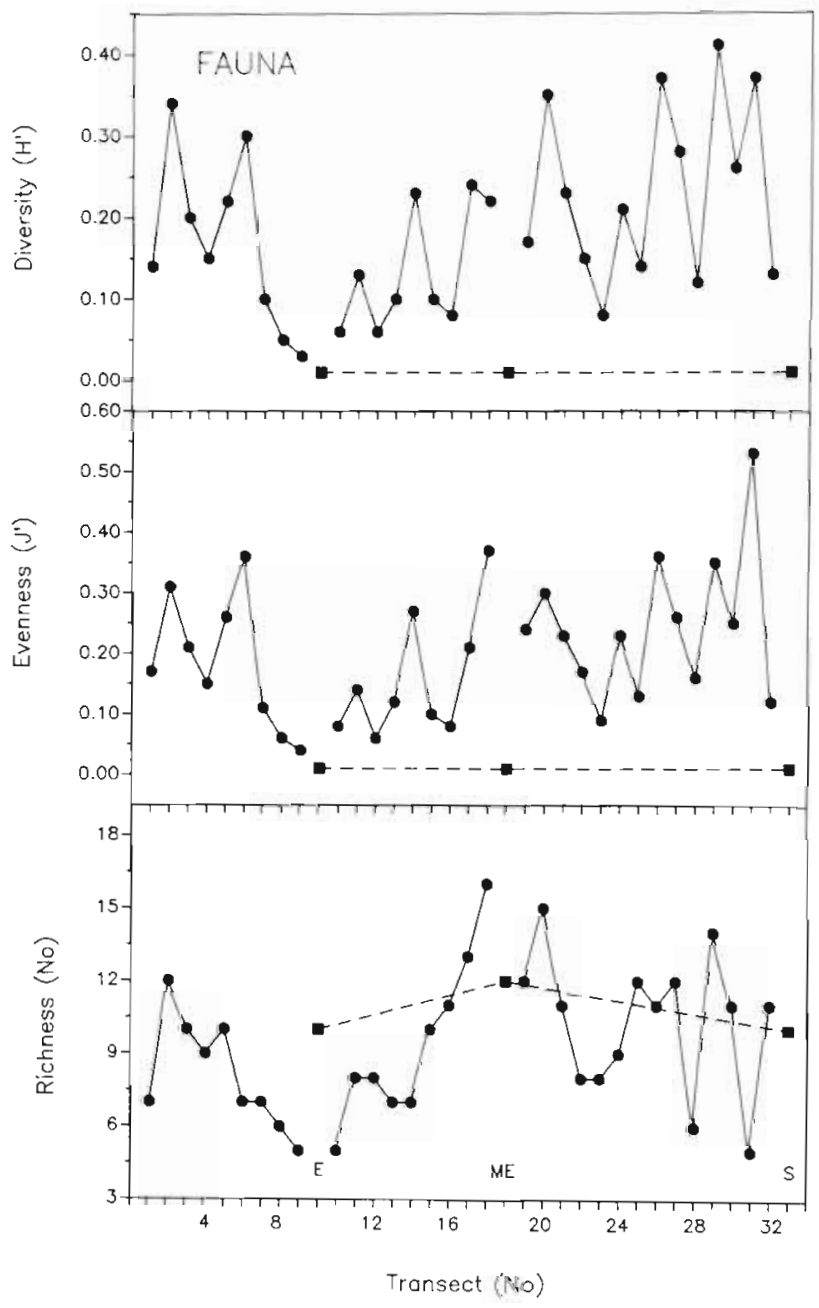

Fig. 7. Diversity, evenness, and richness of fauna at each of the 32 Laurencia zone transects and at the Exposed (E), Moderately-Exposed (ME), and Sheltered (S) station transects (Acanthophora subzone)

displaying the highest richness. Multiple range tests on the adjusted group means were not significant between exposed and sheltered habitats (SNK, $p>0.05)$. Otherwise, pair-wise comparisons between habitats were significant (SNK, $p<0.05$ ). Flora diversity measurements were different among habitats (ANCOVA $F_{2,19}=5.2, p<0.02$ ), with measurements higher in the moderately-exposed and sheltered habitats than in the exposed habitats (SNK, $p<0.05$ ). Floral and faunal evenness or faunal diversity were not significantly different among habitats. When transects were grouped according to Fig. 5 (cluster analysis; removing Transect 19), similar results were achieved.

At Exposed, Moderately-Exposed, and Sheltered stations, significant differences in the algal richmess (species/sample) occurred among stations $\left(F_{2,59}=3.6\right.$, $p<0.05$; after arcsine transformation), with the Exposed, Moderately-Exposed, and Sheitered stations averaging $5.4,6.2$, and 5.0 species sample ${ }^{-1}$, respectively. Pair-wise comparisons between stations were significantly different (SNK, $p<0.05)$, except between the Sheltered and Exposed stations. Pair-wise tests of plant diversity were significant between the Moderately-Exposed and Exposed stations $(t=2.45, p<0.02)$, but not between the Moderately-Exposed and Sheltered stations $(t=1.70, p>0.05)$, and the Exposed and Sheltered stations $(t=0.93, p>0.05)$.

No significant differences in faunal richness occurred among stations $\left(F_{2,59}=0.05, p>0.05\right)$, with averages of $1.9,2.4$ and 2.2 species sample ${ }^{-1}$ at the Exposed, Moderately-Exposed, and Sheltered stations, respectively. Similarly, pair-wise tests of diversity were not significant.

\section{DISCUSSION}

\section{Intermediate-disturbance}

Confirmation of Connell's (1978) intermediate disturbance hypothesis demands demonstrating opposing gradients of competition and disturbance that result in maximal community diversity or richness at intermediate conditions. In our study area, the predictions appear fulfilled after restrictions are placed on the sampling area and model. That is, the sampling area is selected to minimize 'area-effects' and the model restricted to measurements of species richness.

In highly disturbed locations, wave action removes standing crop or limits its production. The abundance and number of fleshy algae are lower at exposed than moderately-exposed sites. Previously, wave-related disturbance has been shown to fragment the thallus of Acanthophora and stunt the growth of Laurencia (Kilar \& McLachlan 1986a,b). In this study, estimates of wave-induced frond losses are highest at exposed locations and decrease into more benign habitats. These results concur with those from depletion curves of Acanthophora which show an increase in waveinduced mortality as wave exposure (water velocity or force) increased (Kilar \& McLachlan 1986b). Our findings are not intuitively obvious, as algae in high-energy or wave-exposed habitats are often smaller, and more densely compact than those in low-energy or benign habitats (Stewart 1968, Hoek 1969, Munda 1972). Several species (e.g. Anadyomene stellata) occur in the moderately-exposed habitats to the left and right of wave-exposed habitats (see maps of Kilar et al. in press), suggesting that recruitment is not the limiting factor. Overall, intense wave exposure reduces the standing crop, diversity, and richness of fleshy macroalgae and benthic fauna.

At moderately disturbed locations, wave action is 
reduced, primary space is utilized more by the competitive dominants, and the standing crop, richness, and diversity of assemblages are greater than in highly disturbed sites. Wave-caused disturbances of fore-reef populations maintain species richness by preventing or slowing the encroachment of the competitive dominants and making space available for ephemerals to recruit, a situation described for many marine habitats (Osman 1977, Huston 1979, 1985 paine 1979, Sousa 1979a,b, Lubchenco 1980). With Acanthophora and Laurencia overgrowing most. species, or dominating available space, space-light competition for primary space increases but is prevented from nearing completion by chronic wavecaused disturbance. The role of disturbance is largely that of inducing diversity and richness by making available space for recruitment and by limiting the period of competitive interaction.

At low-disturbance locations, the prediction is that species richness or diversity should decrease as the competitive dominants outcompete all others at equilibrium. When area effects are removed statistically or by sampling in the Acanthophora subzone, estimates of richness, but not diversity, decrease from the moderately-exposed to sheltered habitats. The elimination of 'area effects' is justifiable, as species-area relationships are well established in terrestrial systems (MacArthur \& Wilson 1967). With the competitive dominants increasing in abundance and other space-holding species decreasing, the predictions of the intermediatedisturbance model appear supported.

Species patterns of standing crop or occurrence provide insights into the intermediate-disturbance model and community structure. Four patterns of species abundance occurred along the wave-exposure gradient (Table 3); 2 patterns are predicted by the model. The first pattern, illustrated by the competitive-dominant, Laurencia, increases in abundance as disturbance pressure (wave action) subsides. The second pattern consists of species that have their highest abundance at intermediate intensities, with competition in sheltered habitats and wave-caused disturbance at exposed habitats presumably reducing their abundance. As this is the most frequent pattern, the intermediate-disturbance model is again supported.

The remaining patterns illustrate the complexity of the fore-reef community. The coralline algae Halimeda opuntia and Amphiroa fragilissima decrease in abundance as wave exposure subsides (Pattern 3). As these species are little affected by wave-related disturbance, they are presumably competitively displaced by fleshy algae in benign habitats. Throughout the Caribbean and the Indo-Pacific, reefs in high-energy environments are known to develop significant accumulations of encrusting calcareous algae (Adey 1978). After our study, an additional 14 species of encrusting algae were identified from exposed, fore-reef sites (R. $H$. Townsand \& J. Norris pers. comm.), making species richness equivalent at the exposed and moderatelyexposed sites. Accordingly, the number of species adapted to intense wave-exposure is as important as intermediate disturbance in determining community richness.

With decreasing wave exposure, community structure in the Laurencia zone is further complicated by sedimentation and habitat complexity. Landward locations of some wave-sheltered transects are inundated by coarse-grain sediments and rubble that reduce the abundance and slow the encroachment of Laurencia (see map of Birkeland et al. 1973). The green alga Dictyosphaeria sp. is most abundant in wave-exposure habitats and in sheltered habitats where sand burial and abrasion are intense (Pattern 4). At locations where sedimentation is not a factor, the competitive dominants increase in standing crop, size (height), density, and branching structure. Within such habitats of increased complexity, Gore et al. (1981) have shown species richness and diversity of faunal assemblages to increase as encounters among predators and prey decrease and available space increases. Similar observations were made by Menge \& Sutherland (1976), Heck \& Wetstone (1977) and Russ (1980). Like area effects', sedimentation and habitat complexity are unavoidable consequences of the wave-exposure gradient. It follows that species richness, which is largely dependent upon the right combinations of species coadjusted in their niches, is independent of the number of species occupying primary space. Several patterns of diversity and richness are possible along disturbance and competition gradients if guilds of species that are unaffected by space-light competition for primary substratum or disturbance-related mortality are included or other forms of disturbance involved. These results compare favorable to those of Lubchenco \& Gaines (1981), Hixon \& Brostoff (1983) and Hixon (1986), who proposed several different outcomes of community structure with varying intensities of herbivory.

\section{Disturbance-mediated competition}

Laurencia is the most widely distributed and abundant macrophyte in the fore-reef. As defined by its ability to sequester and dominate available free space ('grab and hold space strategy'; Sousa 1979a), it is the competitive dominant. Hay (1981) has shown that the 'turf' morphology of Laurencia is well adapted to tolerate periods of tidal emersion, enabling it to maintain space and vegetatively expand its distribution when 
conditions become favorable. The survival of Acanthophora, on the other hand, is improved by occurring in association with dense aggregates of Laurencia that retain water when exposed to air (Hay 1981) and tolerate wave forces. In certain spatially (Acanthophora subzone, sheltered habitat) and/or temporally (2 to 4 wk after tidal emersion) defined conditions, Acanthophora outcompetes Laurencia, but does not exclude it, as Acanthophora is less tolerant of wave-action (Kilar \& McLachlan 1986a) and aerial exposures (Hay 1981). Unlike other perennials on the platform, Laurencia and Acanthophora reproduce throughout the year (Kilar \& McLachlan 1986b). Thus, the success of Laurencia and Acanthophora depends on the types of perturbations and on their ability to acquire and hold space through competition, vegetative expansion, and reproduction.

Acanthophora and Laurencia coexist despite high resource overlap. In sheltered habitats, Acanthophora develops a dense cover of sufficient longevity that reduces the abundance of Laurencia. Competitive displacement is prevented for several reasons. First, mats of Acanthophora entrap and accumulate nascent oxygen which produces sufficient force to remove the mat from its substratum (Kilar \& McLachlan 1986b). Secondly, the holdfast (attachment structure) of Acanthophora and Laurencia acts as a resistant stage (Hay 1981, Kilar 1984). Several generations may be required to weaken the holdfast before exclusion can occur. Thirdly, frequent disturbances occur. Presumably, seasonal emersions of the platform prevent Laurencia from competitively excluding Acanthophora at moderately-exposed habitats and Acanthophora from eliminating Laurencia at sheltered habitats. Similarly, Connell (1976) observed that the physical environment can promote coexistence by inflicting higher mortality on the competitive dominant species. Finally, mutualistic interactions occur. During periods of tidal emersions, Laurencia shaded by Acanthophora is protected from direct effects of sunlight and desiccation (Kilar 1984). The survival of Acanthophora, as previously mentioned, is improved by occurring in association with Laurencia (Hay 1981, this study). Similarly, Dayton (1975) has noted the 'indirect effects' of the competitive-dominant, overstory kelps in protecting the smaller, competitively inferior species from desiccation or radiation damage. Coexistence occurs as the differences in the exploitive strategy of Laurencia and the interference strategy of Acanthophora permit the possibilities of tradeoffs between cost and benefits.

In summary, the fore-reef community at Galeta Point is mediated by chronic and episodic disturbances which control the availability of space and the types and quantities of the competitors. The ability of the dominant perennial species to tolerate recurring natural disturbances appears to determine their abundance and dominance on the reef platform, with competitive abilities assuming more of a secondary role. Littler \& Littler (1981), Grigg (1983), and Lubchenco (1986) have also noted that the biological components of spatial complexity, competition, and recruitment appearing secondarily to influence community structure. Spatial-temporal scaling is critical in understanding competitive interactions and could explain why competition is often difficult to measure or recognize. As to what maintains species richness on coral reefs, these data support the paradigm that periodic disturbances maintain species diversity by preventing competitive exclusions. MacArthur \& Levins' (1964) prediction that the number of dominant species is related to habitat complexity is also confirmed, as the type of a disturbance selects for different guilds of species (e.g. sedimentation, Dictyosphaeria sp.; wave exposure, Halimeda opuntia and coralline algae; tidal emerions, Laurencia). Between opposing gradients of disturbance and competition, species richness increases among those guilds of species competing for primary space and subject to chronic disturbance-caused mortality. Otherwise, the numbers of species adapted to environmental extremes or associated with the competitive dominants may be just as important in determining community richness and diversity.

Acknowledgements. The study was funded by a grant from the Smithsonian Institution's Environmental Science Program. to $J$. Norris and J. Cubit. Additional support was provided to $\mathrm{J}$. Kilar by Postdoctoral Fellowships at the Harbor Branch Oceanographic Institution, Inc. and the Smithsonian Marine Station, Link Port. We thank M. D. Hanisak, K. Bucher, N. Smith, R. Sims, R. Thompson, F. Chang, and M. Garcia, who provided needed support or assistance in the field. This is Contribution No. 707 from the Harbor Branch Oceanographic Institution and Contribution No. 238 from the Smithsonian Marine Station, Link Port.

\section{LITERATURE CITED}

Adey, W. H. (1978). Algal ridges of the Caribbean Sea and West Indies. Phycologia 17: 361-367

Arthur, $W$ (1982). The evolutionary consequences of interspecific competition. In: Macfadyen, A., Ford, E. D. (eds.) Advances in ecological research, Vol.12. Academic Press, New York, p. 127-187

Birkeland, C, Reimer, A. A., Young, J. R. (1973). Effects of oil on tropical shore natural communities in Panama. Federal Water Quality Administration, U.S. Environmental Protection Agency, Project Report \#18050 EFV, Washington, D. C.

Birkeland, C., Reimer, A. A., Young, J. R. (1976). Survey of marine communities in Panama and experiments with oil. U.S. Environmental Protection Agency, Office of Research and Development, Environmental Research Laboratory, Narragansett, Rhode Island 
Connell, J. H. (1970). A predator-prey system in the marine intertidal region. I. Balanus glandula and several predatory species of Thais. Ecol. Monogr. 40: 49-78

Connell, J. H. (1976). Competitive interactions and species diversity of corals. In: Mackie, G. P. (ed.) Coelenterate ecology and behavior Plenum Press, New York, p. $51-58$

Connell, J. H. (1978). Diversity in tropical rain forests and coral reefs. Science 199: 1302-1310

Connell, J. H., Keough, M. J. (1985). Disturbance and patch dynamics of subtidal marine animals on hard substrata. In: Pickett, S. T A., White, P. S. (eds.) The ecology of natural disturbance and patch dynamics. Academic Press, New York, p. 125-151

Connor, J. L. (1985). Seasonal changes in an algal community of a tropical fringing reef in Panama. Dissertation, University of California, Berkeley

Cubit, J. D., Williams, S. L. (1983). The invertebrates of Galeta Reef (Caribbean Panama): a species list and bibliography. Atoll Res. Bull. 269: 1-45

Dayton, P. K. (1971). Competition, disturbance, and community organization: the provision and subsequent utilization of space in a rocky intertidal community. Ecol. Monogr. 41: 351-389

Dayton, P. K. (1975). Experimental evaluation of ecological dominance in a rocky intertidal algal community. Ecol. Monogr. 45: 137-159

Denny, M. W. (1983). A simple device for recording the maximum force exerted on intertidal organisms. Limnol. Oceanogi 28: 1269-1274

Geister, J. (1977). The influence of wave exposure on the ecological zonation of Caribbean coral reefs. In: Taylor, D. L. (ed.) Proc. 3rd Int. Coral Reef Symp. 2. Rosenstiel School of Marine and Atmospheric Sciences, University of Miami, Florida, p. 23-29

Glynn, P. W. (1968). Mass mortality of echinoids and other reef flat organisms coincident with muddy low water exposures in Puerto Rico. Mar. Biol. 1: 226-243

Gore, R. H., Gallaher, E. E., Scotto, L. E., Wilson, K. A. (1981) Studies on decapod crustacea from the Indian River region of Florida. XI. Community composition, structure, biomass and species-areal relationships of seagrass and drift algaeassociated macrocrustaceans. Estuarine coast. Shelf Sci. 12: $485-508$

Grigg, R. W. (1983). Community structure, succession and development of coral reefs in Hawaii. Mar. Ecol. Prog. Ser 11: $1-14$

Grime, J. P. (1979). Plant strategies and vegetation processes Wiley, New York

Hay, M. E. (1981). The functional morphology of turf-forming seaweeds: persistence in stressful marine habitats. Ecology 62: 739-750

Heck, K. L., Jr., Wetstone, G. S. (1977). Habitat complexity and invertebrate species richness and abundance in tropical seagrass meadows. J. Biogeogr. 4: 135-142

Hendler, G. L. (1976). Marine studies - Galeta Point. In: Windsor, D. M. (ed.) 1975 Environmental monitoring and baseline data compiled under the Smithsonian Institution Environmental Science Program: tropical studies. Smithsonian Institution, Washington, D. C., p. 131-249

Hendler, G. L. (1977). The differential effects of seasonal stress and predation on the stability of reef-flat echinoid populations. In: Taylor, D. L. (ed.) Proc. 3rd Int. Coral Reef Symp. 2. Rosenstiel school of Marine and Atmospheric Sciences, University of Miami, Florida, p. 217-223

Hixon, M. A. (1986). Fish predation and local prey diversity In: Simenstad, C. A., Cailliet, G. M. (eds.) Contemporary studies on fish feeding. Dr. W. Junk Publishers, Dordrecht, The Netherlands, p. 235-257

Hixon, M. A., Brostoff, W N. (1983). Damselfish as keystone species in reverse: intermediate disturbance and diversity of reef algae. Science 220: 511-513

Hoek C. van den (1969). Algal vegetation-types along the open coasts of Curaçao, Netherlands Antilles. Proc. K. ned. Akad. Wet. (Sect. C) 72:537-577

Huston, M. (1979). A general hypothesis of species diversity Am. Nat. 113: 81-101

Huston, M. (1985). Patterns of species diversity on coral reefs. A. Rev. Ecol. Syst. 16: 147-177

Hutcheson, K. (1970). A test for comparing diversities based on the Shannon formula. J. theor. Biol. 29: 151-154

Hutchinson, G. E. (1961). The paradox of the plankton. Am. Nat. 95: 137-145

Jackson, J. B. C., Buss, L. (1975). Allelopathy and spatial competition among coral reef invertebrates. Proc. natn. Acad. Sci. U.S.A. 72: 5160-5163

Janzen, D. H. (1970). Herbivores and the numbers of tree species in tropical forests. Am. Nat. 104: 501-528

Kilar, J. A. (1984). Ecological studies of the alga, Acanthophora spicifera (Vahl) Berg. (Rhodophyta, Ceramiales): I. the fragmentation strategy; II. maintenance and persistence in a community dominated by Laurencia papillosa (Forsk.) Grev. Dissertation, Dalhousie University, Halifax

Kilar, J. A., McLachlan, J. (1986a). Branching morphology as an indicator of environmental disturbance: testing the vegetative fragmentation of Acanthophora spicifera and the turf morphology of Laurencia papillosa. Aquat. Bot. 24: 115-130

Kilar, J. A., McLachlan, J. (1986b). Ecological studies of the alga, Acanthophora spicifera (Vahl) Borg. (Ceramiales, Rhodophyta): vegetative fragmentation. J. exp. mar. Biol. Ecol. 104: 1-21

Kilar, J. A., Norris, J. N. (1988). Composition, export, and import of drift vegetation on a tropical plant-dominated, fringing-reef platform (Caribbean Panama). Coral Reefs 7 : 93-103

Kilar, J. A., Norris, J. N., Cubit, J. D., Hay. M. E. (in press). The community structure, seasonal abundance, and zonation of benthic assemblage on a plant-dominated fringing-reef platform (Caribbean Panama). Smithson. Contr. mar. Sci.

Kreb, J. C. (1978). Ecology: the experimental analysis of distribution and abundance. Harper and Row, New York

Littler, M. M., Littler, D. S. (1981). Intertidal macrophyte communities from Pacific Baja California and the Upper Gulf of California: relatively constant vs. environmentally fluctuating systems. Mar. Ecol. Prog. Ser. 4: 145-158

Loya, Y (1976). Recolonization of Red Sea corals affected by natural catastrophes and manmade perturbations. Ecology 57: $278-289$

Lubchenco, J. (1978). Plant species diversity in marine intertidal community: importance of herbivore food preference and algal competitive abilities. Am. Nat. 112: 23-39

Lubchenco, J. (1980). Algal zonation in the New England rocky intertidal community: an experimental analysis. Ecology 61: 333-344

Lubchenco, J. (1986). Relative importance of competition and predation: early colonization by seaweeds in New England. In: Diamond, J., Case. J. J. (eds.) Community ecology. Harper and Row, New York, p. 537-555

Lubchenco, J., Gaines, S. D. (1981). A unified approach to marine plant-herbivore interactions. I. populations and communities. A. Rev. Ecol. Syst. 12: 405-437

MacArthur, R., Levins, R. (1964). Competition, habitat selection and character displacement in a patchy environment Proc. natn. Acad. Sci. U.S.A. 51: 1207-1210 
MacArthur, R., Wilson, E. (1967). The theory of island biogeography. Princeton University Press. Princeton, New Jersey

Menge, B. A. (1976). Organization of the New England rocky intertidal community: role of predation, competition, and environmental heterogeneity, Ecol. Monogr 46: 355-393

Menge, B. A., Sutherland, J. P. (1976). Species diversity gradients: synthesis of the roles of predation, competition, and temporal heterogeneity. Am. Nat. 110: 351-369

Munda, I. (1972). On the chemical composition, distribution, and ecology of some common benthic marine algae from Iceland. Botanica mar. 15: 1-45

Osman, R. W. (1977). The establishment and development of a marine epifaunal community. Ecol. Monogr. 47: 37-63

Paine, R. T. (1966). Food web complexity and species diversity. Am. Nat. 100:67-75

Paine, R. T. (1979). Disaster, catastrophe, and local persistence of the sea palm, Postelsia palmaeformis. Science 205: 685-686

Paine, R. T., Vadas, R. L. (1969). The effects of grazing by sea urchins, Strongylocentrotus spp., on benthic algal populations. Limnol. Oceanogr. 14: 710-719

Pielou, E. C. (1975). Ecological diversity, Wiley, New York

Pimentel, R. A., Smith, J. D. (1986). Bio 5 tat I; a univariate statistical toolbox. Sigma Soft, Placentia, California

This article was submitted to the editor
Romesburg, H. C. (1984). Cluster analysis for researchers. Lifetime Learning Publications, Belmont, California

Russ, G. R. (1980). Effects of predation by fishes, competition, and structural complexity of the substratum on the establishment of a marine epifaunal community. J. exp. mar. Biol. Ecol. 42: 55-69

Shannon, C. E., Weaver, W (1949). The mathematical theory of communication. University of Illinois Press, Urbana, Illinois

Sokal, R. R., Michener, C. D. (1958). A statistical method for evaluating systematic relationships. Univ. Kans. Sci. Bull. 38: $1409-1438$

Sokal, R. R., Rohlf, F. J. (1981). Biometry. W. H. Freeman \& Co., San Francisco

Sousa, W. P. (1979a). Experimental investigations of disturbance and ecological succession in a rocky intertidal algal community. Ecol. Monogr. 49: 227-254

Sousa, W. P. (1979b). Disturbance in marine intertidal bovlder fields: the nonequilibrium maintenance of diversity. Ecol. Monogr. 60: 1225-1239

Stewart, J. G. (1968). Morphological variation in Pterocladia pyramidale. J. Phycol. 4: 76-84

Tilman, D. (1980). Resources: a graphical-mechanistic approach to competition and predation. Am. Nat. 116 : $362-393$

Manuscript first received: September 2, 1988

Revised version accepted: February 22, 1989 